\title{
Małgorzata Olejarz, Emilia Paprzycka, Sylwia Słowińska (red.), „Dyskursy Młodych Andragogów”, t. 16, Wydawnictwo Uniwersytetu Zielonogórskiego, Zielona Góra 2015, ss. 402.
}

Idea powstania Dyskursów Młodych Andragogów jest związana ze spotkaniami podczas Letnich Szkół Młodych Andragogów, których twórcy i organizatorzy pomyśleli o stworzeniu cyklicznej publikacji adresowanej do młodych autorów zainteresowanych edukacją dorosłych. Na jej łamach swoje teksty prezentowali początkowo uczestnicy szkół, aby z czasem poszerzyć krąg o innych badaczy, mieszczących się w podobnych obszarach zainteresowań. Pierwszym redaktorem został inicjator i organizator szkół - prof. Józef Kargul. W 2013 r. publikację przekształcono z serii wydawniczej na czasopismo naukowe, gdzie znalazło się na liście czasopism MNiSW uzyskując cztery punkty, a od 2015 r. (po przejściu ponownej oceny) 10 punktów*.

Na łamach szesnastego tomu czasopisma „Dyskursy Młodych Andragogów" po raz kolejny opublikowane zostały teksty (nie tylko) młodych badaczy, reprezentujących różne ośrodki naukowe**. Ten numer rocznika, podobnie jak poprzednie***, został podzielony na dyskursy, wśród których w tomie znalazły się: poradoznawczy, andragogiczny, edukacji medialnej, animacji

* http://www.dma.wpsnz.uz.zgora.pl/index.php/o-czasopismie (dostęp: 27.02.2016).

** Wśród autorów znaleźli się przedstawiciele Uniwersytetu Zielonogórskiego, Uniwersytetu Wrocławskiego, Uniwersytetu Marii Curie-Skłodowskiej w Lublinie, Uniwersytetu Adama Mickiewicza w Poznaniu, Szkoły Wyższej Psychologii Społecznej, Dolnośląskiej Szkoły Wyższej, Federation University Australia, SGGW w Warszawie, Akademii Górnoczo-Hutniczej w Krakowie, Uniwersytetu Śląskiego w Katowicach, Uniwersytetu Pedagogicznego im. KEN w Krakowie, Uniwersytetu Gdańskego, Akademii Wychowania Fizycznego w Poznaniu.

*** W numerze 15. pojawiły się dyskursy: andragogiczny, poradoznawczy, edukacji kulturalnej oraz genderowy, w tomie 14. dyskurs: andragogiczny, poradoznawczy i metodologiczny, w numerze 13.: andragogiczny, poradoznawczy i interkulturowy, a w 12.: andragogiczny, poradoznawczy i metodologiczny, zob. w: http://www.dma.wpsnz.uz.zgora.pl/index. php/indeks-numerow. 
kultury i genderowy. W ramach owych dyskursów na łamach publikacji ukazało się dwadzieścia sześć artykułów, a także dwa sprawozdania.

Prezentowana pozycja doskonale wpasowuje się w rozważania nad aktualnymi problemami szeroko pojętej edukacji dorosłych, $\mathrm{z}$ uwzględnieniem najnowszego stanu badań czy kierunków zmian. Uwagę czytelnika szesnastego tomu zwraca pochylenie się nad szeroko pojmowaną męskością. Autorki analizują kategorię męskości z perspektywy opinii innych mężczyzn, wizerunku ojca w reklamach oraz celebryty. Dla porównania w poprzednim numerze dominowały zagadnienia związane z rynkiem pracy oraz kobiecością*.

Numer tradycyjnie otwiera dyskurs andragogiczny, na łamach którego pojawiają się kategorie związane ze szkołą wyższą, kompetencjami, uczeniem się, a także szeroko pojętym rozwojem, również w zakresie emocjonalnym (którego znaczenie przypisuje się zazwyczaj okresowi dzieciństwa czy dorastania). W dyskursie znalazły sie treści odnoszące się do oceniania w szkole wyższej i jego kompleksowego ujęcia, pedagogiki przeżyć rozpatrywanej w kontekście dorosłości, wspomnianego rozwoju emocjonalnego dorosłych czy chociażby kontekstów podróżowania. Pojawia się także tematyka związana z wiekiem senioralnym, od doświadczeń szkolnych seniorów konfrontowanych z doświadczeniami szkolnymi młodzieży, po uczenie się starszych mężczyzn.

Wyzwania edukacyjne stały się przedmiotem dociekań w dyskursie poradoznawczym, w którym pochylono sie nad różnymi praktykami w zakresie poradnictwa, a także jego nowymi problemami. Autorzy zwracają uwage na tendencję mediatyzacji w poradnictwie zapośredniczonym, na podstawie której można zaobserwować zmiany i przeobrażania w formach niesienia pomocy. Ponadto pojawia się refleksja nad wyobrażeniem przyszłej pracy poradoznawcy, na konstruktywnej analizie narracji podtrzymujących konflikt czy poradnictwie w zakresie HIV/AIDS.

Dyskurs medialny zdominowały dwa tematy - edukacja medialna oraz kształcenie na odległość w kontekście całożyciowym. Z kolei w animacji kultury zwrócono uwagę na różne formy aktywności twórczej oraz formy oddziaływań artystycznych i społecznych, wśród nich: praktyki muzealne, community art oraz filmy o starości. Warto podkreślić, że rozszerzająca się oferta działań kulturalnych skierowanych do coraz to nowych grup to temat pojawiający się coraz częściej w kontekście rozwijania kompetencji oby-

* por. M. Olejarz (red.), „Dyskursy Młodych Andragogów” 2014, t. 15, Zielona Góra. 
wateli Europy, a w szczególności grup zagrożonych wykluczeniem, m.in. ze względu na pochodzenie czy wiek*.

Na szczególną uwagę zasługuje ostatni dział - dyskurs gender. Tekst odnoszący się do niemęskich mężczyzn tylko potwierdza stereotypowe postrzeganie ról społecznych i zawodowych, a na przykładzie narracji na temat zawodu pielęgniarza wzmacnia tezę o podziale na zawody typowo męskie i kobiece. Autorka zwraca uwagę na potrzebę redefinicji pojęcia męskości, a jej analizy wskazują, że badani nie przewidują długiej kariery mężczyzn w zawodach niemęskich**. W dziale pojawiają się liczne odwołania do kategorii płci kulturowej Raewyn Connell. Redefinicja męskości została omówiona także w ramach popularnych seriali, a męskość przeanalizowana również na przykładzie celebryty - Kuby Wojewódzkiego. Kolejno przedstawione zostały różne typy ojca pokazywane w reklamie telewizyjnej oraz męskość w wybranych podręcznikach.

Całość zamykają dwa sprawozdania - z projektu badań dotyczących inicjatyw osób 50+, a także relacji z III Transdyscyplinarnego Sympozjum Badań Jakościowych.

Prezentowany numer z powodzeniem odpowiada na aktualne potrzeby i wyzwania edukacji dorosłych, które zostały tu przedstawione w nawiązaniu do najnowszych trendów czy badań. Autorzy są czujni na pojawiające się w społeczeństwie problemy czy tendencje, takie jak męskość czy nowe potrzeby edukacyjne, w tym szczególnie potrzeby osób w wieku senioralnym. $\mathrm{Na}$ uwagę zasługują zarówno konteksty prowadzonych analiz, jak i różnorodność prezentowanych zagadnień.

Iwona Murawska

* Szczególnie w odniesieniu do programów finansowanych z Funduszy Europejskich.

** M. Herudzińska, Męskość na manowcach? (Nie)męski mężczyzna w opiniach mężczyzn, [w:] M. Olejarz, E. Paprzycka, S. Słowińska (red.), „Dyskursy Młodych Andragogów” 2015, t. 16, Zielona Góra, s. 293-309. 